Theatre Research in Canada

Recherches théâtrales au Canada

\title{
Liberal Education, Entrepreneurship, and the Law
}

\section{Shelley Scott}

Volume 39, Number 1, 2018

URI: https://id.erudit.org/iderudit/1055473ar

DOI: https://doi.org/10.7202/1055473ar

See table of contents

Publisher(s)

Graduate Centre for the Study of Drama, University of Toronto

ISSN

1196-1198 (print)

1913-9101 (digital)

Explore this journal

Cite this document

Scott, S. (2018). Liberal Education, Entrepreneurship, and the Law. Theatre Research in Canada / Recherches théâtrales au Canada, 39(1).

https://doi.org/10.7202/1055473ar

All Rights Reserved (C) Theatre Research in Canada / Recherches théâtrales au Canada, 2018
This document is protected by copyright law. Use of the services of Érudit (including reproduction) is subject to its terms and conditions, which can be viewed online.

https://apropos.erudit.org/en/users/policy-on-use/ 


\title{
Liberal Education, Entrepreneurship, and the Law
}

\author{
SHELLEY SCOTT
}

As our Calendar states, "Liberal Education has been a community tradition at the University of Lethbridge since its founding." But as the institution has moved to incorporate professional faculties (such as Health Sciences and Management); grow its graduate program, particularly in the sciences; and build its research profile, the understanding of liberal education has devolved into a requirement that students take a "breadth" of courses and tends to be perceived as an onerous burden. All undergrads are expected to take four courses from three liberal education lists. This may be particularly resisted by Fine Arts students, who already have some of the most intensive major requirements of any students across the University, but who still balk at having to take courses outside their Faculty or even department because such courses are not seen as contributing to their "training." I see this as a tension between conservatory expectations within a liberal education model.

I served on the University of Lethbridge Liberal Education Revitalization Team (LERT) for three years. In the summer of 2017 , the mandate of the Team was fulfilled with the creation of a School of Liberal Education, which will now oversee the lists plus sixteen liberal education courses. According to Team leader Shelly Wismath, "What's significant is this new administrative structure. We're not one program among many, we're now seen as having a university-wide impact" (qtd. in "U of Lethbridge Recommits" Io). In direct contrast to the institutional experience described by Moira Day in her essay, Lethbridge chose to amplify liberal education as a unifying philosophy. LERT defined liberal education with a "four-pillar" model, emphasizing not only breadth of learning but also cross-disciplinary connections, critical thinking, and civic engagement. As Wismath explains, "We have complex problems ahead of us in the world and we want our students to be equipped to solve them for the public good" (ro).

I believe that theatre courses intersect with liberal education most fruitfully when viewed from the perspective of outcomes for theatre graduates, especially in the fields of, perhaps surprisingly, entrepreneurship and the law. Like many other Canadian institutions, Lethbridge is committed to the creation of trans-disciplinary maker spaces where students from different areas can interact and come up with innovative projects that have applicable social value, but are not necessarily commercial - our program is called Agility - but I would argue that this is exactly what theatre students already do. Librarian Steven Bell notes, "Encouraging students to engage in entrepreneurial pursuits is nothing new for higher education," but traditionally such concerns were associated only with business schools. Today, however, liberal education programs are re-casting themselves as "incubators," and "Finding ways to help liberal arts majors tap into their inner creativity to boost innovation." Bell points out, "it will take time to figure out exactly what it means to 'entrepreneurize' the curriculum" (Bell). But in my opinion, theatre is entrepreneurial already, we only need to help students 
recognize all of their university experiences, both inside and outside the classroom, as part of their liberal education.

In his article on "The Sustainable College," Daniel F. Sullivan argues that one of its hallmarks is a pedagogical approach "that is both challenging academically and based on eliciting high levels of student engagement," one that "involves much active learning and little passive learning" (2). So what are the practical skills imparted through liberal education and which ones intersect with theatre studies? According to Sullivan, they are: "inquiry and analysis, critical and creative thinking, integrative and reflective thinking, written and oral communication, quantitative and information literacy, intercultural understanding, and teamwork and problem solving" (3). As Claire Carolan points out, theatre develops some of those skills better than any other discipline.

Some of the most articulate champions of these skills that I have spoken with are former students who have chosen to pursue law school. Jennifer Biernaskie graduated in 1999 with a BA in Drama from the University of Lethbridge and then completed her law education at Dalhousie, and is now a Partner at McLennan Ross LLP in Calgary. Jen tells people that a Drama degree is a "great foundation for pretty much anything." I asked Jen what skills, qualities, and experiences from her Drama degree are applicable to her now as a lawyer. Jen replied:

general confidence, being comfortable speaking publicly, thinking on your feet, [...] collaborative brainstorming, and creative problem solving. It set me up for being comfortable stepping into roles/arguments I may not personally believe in, but somebody needs to take on to make the system work. I sometimes compare my job to the job of a director, because I think in both you need to be a "jack of all trades" who likes learning about everything and taking on new challenges. I think studying in a liberal arts university helped with that as well.

(Biernaskie)

Abilities such as being able to conduct research, build an argument, and advocate for a position may not be immediately identified with theatre, but they are in fact integral. When we consider the importance of these kinds of skills for any profession, and the success of our graduates in pursuits beyond being a theatre artist, it seems obvious that we can legitimately promote Drama programs as an excellent home for promoting liberal education values.

The University of Lethbridge can also boast a number of graduates who have gone on to become theatre producers, and the epitome of the successful liberal education graduate must surely be the theatre artists who establish and run their own independent company and make their own work: applying their general knowledge and skills to particular new and changing circumstances all the time, having to be infinitely adaptable and resourceful. Even if one argues that it is their practical training that allows them to design, build, light, costume, and perform their show, it is their liberal education background that gives them the idea of what to do a show about, how to raise funds, and how to market it.

Sullivan argues that, to produce students like these, the university needs to provide them with "purposeful, active, and collaborative learning," that the student must experience "quality interactions with faculty members," and have opportunities for internships and collaborative research (3-4). Each of these could be described as what happens in a campus 
production, which is why they should be understood, by administrators, faculty, and students, as undergraduate research. As important as it is for these entrepreneurial activities to be acknowledged, it is even more important that students reflect upon and think more broadly about their value as part of a liberal education. Ultimately, we need students to understand that a liberal education is exactly what they want.

\section{Works Cited}

Bell, Steven. “'Welcome to Entrepreneurship U, Part One,' From the Bell Tower.” Library fournal, I9 Aug. 2015. Web. 23 Nov. 2015.

Biernaskie, Jennifer. "Questions for panel presentation.” I March 2017. Email.

Sullivan, Daniel F. "The Sustainable College: Thriving and Serving the Nation in the $2 \mathrm{I}^{\text {st }}$ Century." AGB: Association of Governing Boards of Universities and College, May/June 2015. I-8. Web. 23 Nov. 2015.

"U of Lethbridge Recommits to Liberal Education." University Affairs, June-July 2017. Io. Print. 